\title{
Oxidative and biochemical profile of Gyr dairy heifers during the peripartum period
}

[Perfil oxidativo e bioquímico em novilhas Gir leiteiras durante o periparto]

\author{
H.C.P.M. Mendes ${ }^{1}$ (D) F.O. Paes Leme ${ }^{2 *}$ (D) P.M.P.N. Penido ${ }^{3}$, A. Oliveira ${ }^{4}$, \\ L. Arnhold ${ }^{5}$ iD , L. El Faro ${ }^{6}$ (D) \\ ${ }^{1}$ Graduate, Instituto de Zootecnia, Centro de Pesquisas em Bovinos de Corte, Sertãozinho, SP, Brasil \\ ${ }^{2}$ Universidade Federal de Minas Gerais, Escola de Veterinária, Belo Horizonte, MG, Brasil \\ ${ }^{3}$ Universidade Federal de Goiás, Escola de Veterinária e Zootecnia, Goiânia, GO, Brasil \\ ${ }^{4}$ Empresa de Pesquisa Agropecuária de Minas Gerais, Uberaba, MG, Brasil \\ ${ }^{5}$ Fundação de Amparo à Pesquisa do Estado de São Paulo, Fapesp, São Paulo, SP, Brasil \\ ${ }^{6}$ Instituto de Zootecnia, Centro de Pesquisas em Bovinos de Corte, Sertãozinho, SP, Brasil
}

\begin{abstract}
O período de transição em vacas leiteiras aumenta o suprimento de oxigênio aos tecidos e a produção de espécies reativas de oxigênio. Junto com o comprometimento do sistema antioxidante, gera estresse oxidativo, que pode estar ligado ao desenvolvimento de diversas doenças. Este estudo teve como objetivo avaliar o estresse oxidativo em 35 novilhas leiteiras Gir, durante o período periparto. Foram analisados ácido úrico, cobre, ferro, zinco, albumina, bilirrubina total, superóxido dismutase (SOD) e glutationa peroxidase (GSH-Px). Um modelo linear com distribuição de Poisson foi aplicado usando o procedimento GENMOD. A primeira medida (30d antes do parto) foi considerada como referência (T0), e as amostras foram coletadas 16 dias antes do parto (T1) e sete (T2), 14 (T3), 28 (T4) e 42 dias pós-parto (T5). Cobre, zinco e albumina variaram dentro da faixa de referência, apesar de ter havido aumento no cobre de 45,92\% no T3. Os níveis de ácido úrico aumentaram durante o período de transição, sem diferença significativa até 16 dias pré-parto, quando foi observado aumento de 67,57\%, sendo sua maior concentração observada em T4. A SOD teve um aumento maior (300\%) do que a GSH-Px (36\%) no final do período experimental, acompanhada por adaptações bioquímicas para garantir uma resposta antioxidante eficaz. Dessa forma, pode-se concluir que o período periparto causa estresse oxidativo em novilhas leiteiras Gir.
\end{abstract}

Palavras-chave: período de transição, estresse oxidativo, superóxido dismutase, glutationa peroxidase

\section{RESUMO}

O período de transição em vacas leiteiras aumenta o suprimento de oxigênio aos tecidos e a produção de espécies reativas de oxigênio. Junto com o comprometimento do sistema antioxidante, gera estresse oxidativo que pode estar ligado ao desenvolvimento de diversas doenças. Este estudo teve como objetivo avaliar o estresse oxidativo em 35 novilhas leiteiras Gir durante o período periparto. Foram analisados ácido úrico, cobre, ferro, zinco, albumina, bilirrubina total, superóxido dismutase (SOD) e glutationa peroxidase (GSH-Px). Um modelo linear com distribuição de Poisson foi aplicado usando o procedimento GENMOD. A primeira medida (30d antes do parto) foi considerada como referência (TO) e as amostras foram coletadas 16 dias antes do parto (T1) e 7 (T2), 14 (T3), 28 (T4) e 42 dias pós-parto (T5). Cobre, zinco e albumina variaram dentro da faixa de referência, apesar de um aumento no cobre de 45,92\% no T3. Os níveis de ácido úrico aumentaram durante o período de transição, sem diferença significativa até 16 dias pré-parto, quando foi observado um aumento de 67,57\%, sendo sua maior concentração observada em T4. A SOD teve um aumento maior (300\%) do que GSH-Px (36\%) no final do período experimental, acompanhada por adaptações bioquímicas para garantir uma resposta antioxidante eficaz. Dessa forma, pode-se concluir que o período periparto causa estresse oxidativo em novilhas leiteiras Gir.

Palavras-chave: período de transição, estresse oxidative, superóxido dismutase, glutationa peroxidase

*Corresponding author: fabiolapaesleme@ vetufmg.edu.br

Submitted: December 2, 2020. Accepted: June 15, 2021. 


\section{INTRODUCTION}

The transition period of dairy cows is characterized by the shift from the dry to the lactation period, as well as by homeostatic and hormonal changes and metabolic and physiological stresses. Therefore, this is a delicate period in terms of the productivity, profitability, and health of cows (Drackley, 1999; LeBlanc, 2010). The changes in the physiology of transition cows are accompanied by great energy demands and the need for increased oxygen supply to tissues, with a consequent increase in the production of reactive oxygen species (ROS) (Drackey, 1999; Lykkesfeldt and Svendsen, 2007). The increased formation of ROS, along with antioxidant system impairment, generates cellular or systemic oxidative stress. In livestock, oxidative stress can be caused by management related conditions, including important situations for the welfare and productivity of animals, such as environment shifts as well as breastfeeding and milking itself that can be associated with stress and the disease's development (Lykkesfeldt and Svendsen, 2007). The behavioral changes of animals in response to stress are intimately linked to the definition of animal welfare since the daily handling of animals and how handling is done influence their productivity, health and behavior (Hötzel et al., 2005).

Biochemical profile analysis is an important tool in the laboratory evaluation of animals. This profile reflects the physiological situation of the individual or herd and assists the veterinarian in the interpretation of diseases that can arise from metabolic disturbances, individual adaptations, morpho functional alterations in organs, stress, and other situations that occur during the peripartum period (González and Scheffer, 2003). Superoxide dismutase (SOD), and glutathione peroxidase (GSH-Px) are the main enzymatic antioxidant defense systems in the cell (Halliwell, 1995) while uric acid can bind to copper ions, reducing their availability for reactions that increase oxidative stress in the body (Einsele et al., 1987; Glantzounis et al., 2005). Other ions can also participate in the Fenton reaction and stimulate free radicals to increase the oxidative state. Albumin is well known for buffering many reactions and hyperbilirubinemia is associated with an increase in antioxidant defenses such as SOD and GSH-Px and with a decrease in oxidants in several species (Glantzounis et al., 2005). Most biochemical panels used to assemble the oxidative status as well as the systemic conditions include not only antioxidant and liver enzymes, but urea, creatinine, protein, albumin, cholesterol and triglycerides as performed by Lemos (2015).

The aim of this study was to evaluate oxidative stress in Gyr dairy heifers during the peripartum period by analysis of biochemical profile and the antioxidant enzymes superoxide dismutase (SOD), and glutathione peroxidase (GSH-Px).

\section{MATERIAL AND METHODS}

The project was approved by the ethics committee in animal research/EPAMIG (n. 05/2017). The experiment included 35 dairy Gyr heifers during the prepartum (30 days before calving) and postpartum period (up to 42 days of lactation) and was conducted at the Getúlio Vargas Experimental Station of Empresa de Pesquisa Agropecuária de Minas Gerais (EPAMIG), Uberaba, Minas Gerais, Brazil.

All animals in the study were submitted to the same feeding management, which consisted of rotational grazing on Brachiaria brizantha, Marandu cultivar, with 45 days of rest and 4 days of occupation during the dry period. Additionally, salt-protein supplement was offered in order to maintain about 2-3 AU/ha and to obtain a weight gain of $250 \mathrm{~g} / \mathrm{animal} / \mathrm{day}$. About 30 days before calving, females started receiving $2 \mathrm{~kg}$ of concentrate and corn silage, as the farm management protocol.

During lactation, the animals were milked twice a day in a mechanical tandem milking station, with a pit and 12 stands. At the time of milking, the calf had access to a posterior quarter (left or right) of the udder due to the need of the calf's presence in order to favor the milk ejection. The calf was separated from the cow immediately after milking.

Blood samples were collected by puncture of the caudal vein into commercial vacuum tubes with heparin and EDTA and without anticoagulant. After being separated, the serum was stored for latter analysis. This was elected because of the similarity to what is most commonly used in field.

Two samples were collected during the prepartum period (days 30 and 16). In the postpartum period, blood samples were collected 
on days 7, 14, 28 and 42. The times were chosen for being the most representative during the development of mammary gland and the calf. Results from samples obtained from 35 healthy Gyr dairy heifers were used as reference range for the animals of this study.

The oxidative status was evaluated by determining the enzymes glutathione peroxidase (GSH-Px) and superoxide dismutase (SOD) in erythrocytes pellets according to the specifications of the commercial kits used $\left(\right.$ Randox $\left.^{\circledR}\right)$. Fluorescence readings were obtained with a Cobas Mira Plus ${ }^{\circledR}$ analyzer (Roche) and the results were normalized to hemoglobin concentration.

The tubes without anticoagulant were centrifuged at $2000 \mathrm{rpm}$ for $6 \mathrm{~min}$ and serum samples were separated in duplicate and frozen at $-20^{\circ} \mathrm{C}$ in Eppendorf $^{\circledR}$ microtubes for subsequent biochemical analysis. Albumin, uric acid, copper, zinc, iron, and total bilirubin were analyzed using commercial kits (Biotécnica ${ }^{\circledR}$ ) according to manufacturer specifications in a semi-automated spectrophotometer (Cobas Mira Plus ${ }^{\circledR}$, Roche). All analyses were carried out at the Research Support Laboratory (LaPeq) of Departamento de Clínica e Cirurgia Veterinárias (DCCV) from Universidade Federal de Minas Gerais.

A completely randomized design was applied, in which the animals were evaluated at six different time points. Normality and homoscedasticity of the variables were tested by the Kolmogorov-Smirnov and Shapiro-Wilk tests. The observed means and standard deviations of the analytes (uric acid, copper, iron, zinc, albumin, total bilirubin, SOD, and GSH-Px) were obtained with PROC MEANS (SAS 9.2, 2012). The statistical analyses were performed by applying a generalized linear model with Poisson distribution using the GENMOD procedure (SAS 9.2, 2012). The LSMEANS option was used to obtain estimated means and standard errors. The following sampling days were defined: 30 days before calving (T1), 16 days before calving (T2), 7 days postpartum (T3), 14 days postpartum (T4), 28 days postpartum (T5) and 42 days postpartum (T6) The results were submitted to normality tests, so that they could be analyzed by ANOVA or by the Spearman test. The statistical software used was SAS and the significance level adopted was $95 \%$ ( $\mathrm{p}<0.05$ ) for all variables.

In order to better explain and quantitative increase or decrease of analytes, a direction calculus was done. The behavior also had different characteristics, so that the percentages (magnitude\%) of increase (+) or decrease (-) in concentrations or activities were tabulated.

\section{RESULTS}

After analysis using the Kolmogorov-Smirnov and Shapiro-Wilk tests, no variable was considered normal, so the results were submitted to the Speraman test for comparison of groups and times.

Table 1 shows means \pm 1 standard deviation from 35 Gyr dairy heifers that were chosen to establish the reference range to be compared to the Gyr dairy heifers at different sampling times during peripartum. This procedure is justified because of the lack of references in Zebu animals, especially for antioxidative profile analytes.

Table 1. Observed median \pm standard error and reference range of the concentration of biochemical analytes and antioxidant enzymes in Gyr dairy heifers $(n=35)$

\begin{tabular}{lcc}
\hline \multicolumn{1}{c}{ Variable } & Median \pm standard error & Reference range \\
\hline & Biochemical profile & \\
Albumin $(\mathrm{g} / \mathrm{L})$ & $31.80 \pm 0.28$ & $30.48-33.84$ \\
Uric acid $(\mathrm{mmol} / \mathrm{L})$ & $16.07 \pm 1.64$ & $6.96-26.34$ \\
Total bilirubin $(\mu \mathrm{mol} / \mathrm{L})$ & $3.66 \pm 0.40$ & $2.22-6.96$ \\
Copper $(\mu \mathrm{mol} / \mathrm{L})$ & $101.85 \pm 5.92$ & $80.67-150.67$ \\
Iron $(\mu \mathrm{mol} / \mathrm{L})$ & $107.40 \pm 9.46$ & $57.84-169.80$ \\
Zinc $(\mu \mathrm{mol} / \mathrm{L})$ & $15.08 \pm 2.85$ & $2.18-35.92$ \\
& Antioxidant enzymes & \\
Superoxide dismutase $(\mathrm{U} / \mathrm{mL})$ & $76.26 \pm 4.07$ & $52.12-100.30$ \\
Glutathione peroxidase $(\mathrm{U} / \mathrm{L})$ & $744.99 \pm 13.44$ & $663.56-822.52$ \\
\hline
\end{tabular}


Analysis of variance of the biochemical profile and antioxidant enzymes indicated a significant difference in some analytes between sampling times. The estimated means are shown in Table 2 and Fig. 1. The magnitude and direction (increase or decrease) of the variation in the traits analyzed at each time point in relation to the first dosage are shown in Table 3 in order to better understand the clinical relevance.

\section{DISCUSSION}

SOD activity increased by $149.52 \%$ above the upper limit of the reference range established for the prepartum period (T0). This increase in SOD was progressive, reaching a value that was $313.3 \%$ higher than those observed at T0. GSH-Px started to increase at about 16 days prepartum and its increase was also progressive, with a $36.45 \%$ higher average at 42 days postpartum compared to T0. The Spearman correlation coefficient of $55 \%$ demonstrates a positive and strong association between SOD and GSH-Px, confirming that an increase in one enzyme leads to an increase in the other. For these two enzymes, a significant difference was observed between points. In addition, SOD and GSH-Px activities were above the range established at $\mathrm{T} 0$ from $\mathrm{T} 1$ to $\mathrm{T} 5$ and from $\mathrm{T} 2$ to $\mathrm{T} 5$, respectively. This finding reinforces the idea that the increase in SOD and GSH-Px activities during the peripartum period is an antioxidant response to possible oxidative stress according to other studies (Bernabucci et al., 2002; Castillo et al., 2005). Halliwell (1995), postulated that SOD and GSH-Px are the main enzymatic antioxidant defense systems in the cell. The SOD, for example convert superoxide to hydrogen peroxide and the latter to other reduced compounds.

Higher SOD activity was observed in the present study, with the magnitude of the increase being more expressive than GSH-Px, indicating that SOD would be a better marker of the antioxidant response in Gyr dairy heifers. In contrast, Bernabucci et al. (2005) obtained greater variations in mean GSH-Px activity when comparing the prepartum $(650 \pm 0.31 \mathrm{IU} / \mathrm{L})$ and postpartum $(1,610 \pm 0.28 \mathrm{IU} / \mathrm{L})$ periods in Holstein cows with average body conditions cores, indicating GSH-Px as a better marker of the antioxidant response.

Table 2. Estimated medians \pm standard error of the concentration of antioxidative stress analytes in Gyr dairy heifers $(n=35)$ at different sampling times during peripartum

\begin{tabular}{|c|c|c|c|c|c|}
\hline \multicolumn{6}{|c|}{ Time } \\
\hline Reference range* & $\mathrm{T} 1$ & $\mathrm{~T} 2$ & T3 & $\mathrm{T} 4$ & T5 \\
\hline \multicolumn{6}{|c|}{ Albumin (g/L) } \\
\hline $31.80 \pm 0.28 \mathrm{C}$ & $31.50 \pm 0.94 \mathrm{~B}$ & $\begin{array}{c}33.30 \pm 0.42 \mathrm{BC} \\
\text { Uric acid }(\end{array}$ & $\begin{array}{l}34.30 \pm 1.46 \mathrm{ABC} \\
\text { amol/L) }\end{array}$ & $31.80 \pm 0.70 \mathrm{~A}$ & $32.70 \pm 1.03 \mathrm{AB}$ \\
\hline \multicolumn{3}{|c|}{ Total bilirubin $(\mu \mathrm{mol} / \mathrm{L})$} & $\begin{array}{l}29.75 \pm 3.57 \mathrm{AC} \\
(\mu \mathrm{mol} / \mathrm{L})\end{array}$ & $19.93 \pm 2.01 \mathrm{~A}$ & $35.70 \pm 3.93 \mathrm{~A}$ \\
\hline $3.66 \pm 0.40 \mathrm{~A}$ & $3.98 \pm 0.43 \mathrm{~B}$ & $2.80 \pm 0.24 \mathrm{~A}$ & $2.87 \pm 0.31 \mathrm{~A}$ & $4.08 \pm 0.37 \mathrm{~B}$ & $2.74 \pm 0.26 \mathrm{~B}$ \\
\hline \multicolumn{6}{|c|}{ Copper $(\mu \mathrm{mol} / \mathrm{L})$} \\
\hline $101.85 \pm 5.92 \mathrm{BC}$ & $111.27 \pm 7.23 \mathrm{~A}$ & $\begin{array}{r}144.58 \pm 10.82 \mathrm{~B} \\
\text { Iron }(\mu \mathrm{r}\end{array}$ & $\begin{array}{l}104.14 \pm 3.17 \mathrm{BD} \\
\mathrm{ol} / \mathrm{L})\end{array}$ & $121.33 \pm 5.71 \mathrm{C}$ & $99.55 \pm 7.30 \mathrm{CD}$ \\
\hline \multicolumn{6}{|c|}{ Zinc $(\mu \mathrm{mol} / \mathrm{L})$} \\
\hline $15.08 \pm 2.85 \mathrm{BC}$ & $13.32 \pm 1.71 \mathrm{D}$ & $\begin{array}{l}12.25 \pm 1.04 \mathrm{CD} \\
\text { Superoxide disn }\end{array}$ & $\begin{array}{l}18.03 \pm 1.24 \mathrm{CDE} \\
\text { atase }(\mathrm{U} / \mathrm{mL})\end{array}$ & $12.29 \pm 1.56 \mathrm{BE}$ & $26.58 \pm 1.00 \mathrm{~A}$ \\
\hline \multicolumn{5}{|c|}{ Glutathione peroxidase (U/L) } & $398.98 \pm 23.47 \mathrm{~A}$ \\
\hline $744.99 \pm 13.44 \mathrm{~F}$ & $850.81 \pm 29.39 \mathrm{E}$ & $787.60 \pm 18.08 \mathrm{D}$ & $875.78 \pm 32.86 \mathrm{C}$ & $837.36 \pm 25.62 \mathrm{~B}$ & $946.13 \pm 32.43 \mathrm{~A}$ \\
\hline
\end{tabular}

*Reference range obtained from 35 healthy Gyr dairy heifers. T1: 16 days before calving; T2: 7 days postpartum; T3:14 days postpartum; T4: 28 days postpartum; T5: 42 days postpartum. Means in the same row followed by different letters differ significantly between sampling times $(\mathrm{p}<0.05)$. 
Mendes et al.
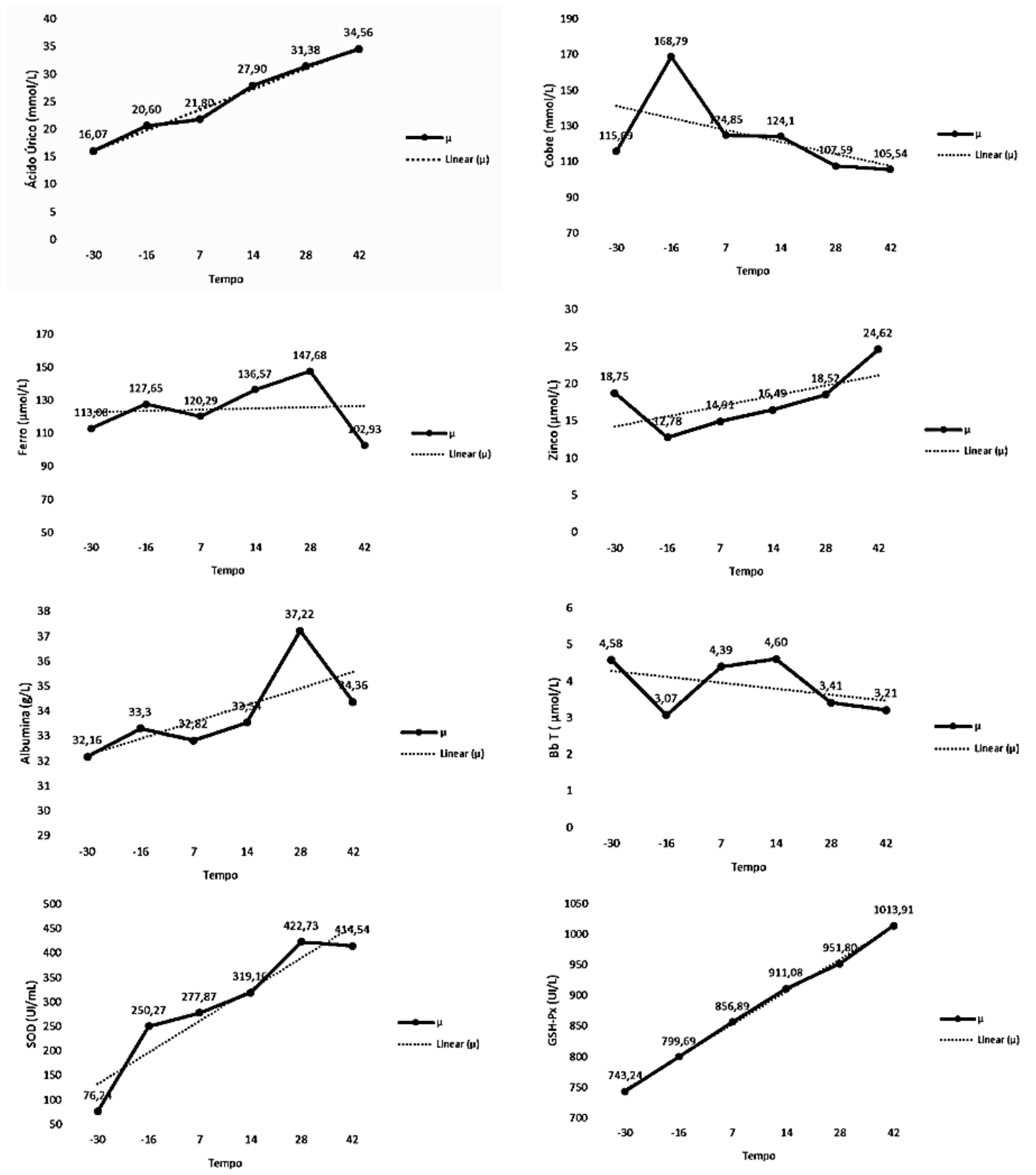

Figure 1. Median values and linear trend of the analytes in T1 (-16), T2 (7), T3 (14), T4 (28), and T5 (42 days) in relation to the calving date. -30 Represent the result of control animals (reference range for this study). 
Oxidative and biochemical...

Table 3. Magnitude (\%) and direction of the variation increase (+) or decrease (-) in mean values of the antioxidative status markers in Gyr dairy heifers at different sampling times in the peripartum period

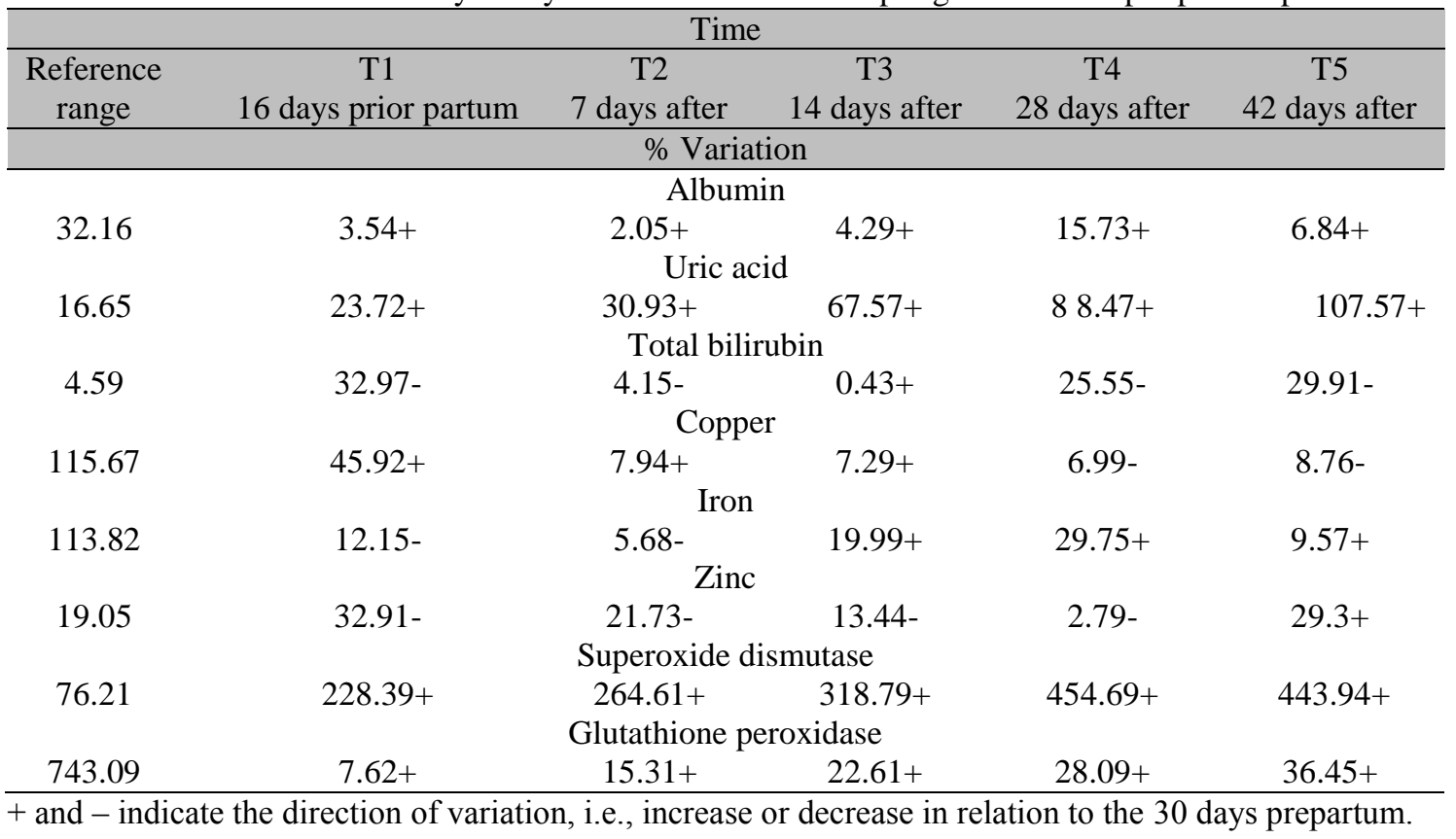

The increase in uric acid showed a linear and positive statistical trend during the transition period, with no significant difference ( $p>0.05$ ) in levels until approximately 14 days postpartum, when an increase of $67.57 \%$ in this metabolite was observed compared to T0. The mean uric acid concentrations during late puerperium (after postpartum day 2) differed $(\mathrm{p}<0.05)$ from those found during prepartum and early puerperium (up to postpartum day 7). An increase of up to $107.57 \%$ in this concentration was observed at 42 days postpartum. Uric acid can bind to copper ions, reducing their availability for reactions that increase oxidative stress in the body (Einsele et al., 1987; Glantzounis et al., 2005). This fact might explain the inverse trend between uric acid and copper in this experiment, with copper decreasing during the postpartum period, although Spearman's correlation coefficient between these analytes was practically zero. The trend of uric acid characterized by different means after postpartum day 14 may have been influenced by the proximity of peak lactation, which is close to 28 days in the Gyr breed, or by increased dry matter intake with advancing lactation. The correlation coefficient between uric acid and SOD was $0.26(\mathrm{p}=0.0001)$, supporting the interpretation that the increase in one analyte leads to an increase in the other and both participate in the antioxidant process.
Analysis of copper, except for the mean obtained at T1 (16 days prepartum), showed that the values remained within the reference range given by the mean and standard deviation at T0 (80.67 to $150.67 \mu \mathrm{g} / \mathrm{dL}$ ), and the range reported in the literature of 63 to $140 \mu \mathrm{g} / \mathrm{dL}$ (Kaneko et al., 2008). There was an increase of $45.92 \%$ in mean copper content at $\mathrm{T} 1$ (16 days prepartum) compared to $\mathrm{T} 0$ $(115.67 \mu \mathrm{g} / \mathrm{dL})$ and the mean value differed significantly compared to the other sampling times.

Copper is distributed throughout the body and acts as a cofactor of several enzymes. It is rapidly consumed during metabolic or enzymatic processes, a fact that may explain its decline. Hence, copper deficiency, even if marginal, can lead to the development of symptoms that affect a wide range of tissues. Hypocuprosis would therefore be a limiting factor for adequate antioxidant activity in the body, as observed in the study of Abba et al. (2000) in which hypocupremic animals exhibited more chromosomal aberrations resulting from the lower catalytic activity of SOD/Cu-Zn (SOD1) and greater oxidative stress. In the present study there was a decrease in cooper concentration probably due to the consumption during the SOD1 increase activity what could be related to this antioxidant response according to Azab et 
al. (1992) discussed previously. Although of low magnitude, the correlation estimate between copper and SOD was negative. This finding agrees with the decline in this micromineral with increasing concentration of the antioxidant enzyme. The same correlation was observed between copper and GSH-Px.

The iron concentrations remained within reference range obtained at $\mathrm{T} 0 \quad(57$ to $169.8 \mu \mathrm{mol} / \mathrm{L}$ ) and no significant difference was observed, indicating the absence of variation in this mineral during the study. Kaneko et al. (2008) reported an iron reference range of 10.2 to $29 \mu \mathrm{mol} / \mathrm{L}$ for cattle, which is much lower than what was found in the current study. Serum iron showed the same trend in all animals in the experiment, with the observation of high blood levels. The elevated serum iron levels may indicate the saturation of iron-binding sites on transferrin and a consequent increase in circulating levels of this mineral, increasing its availability for lipid peroxidation and the occurrence of oxidative stress. The possible causes of the homogenously elevated iron levels need to be better elucidated since the animals showed no clinical signs of iron intoxication. The quantification of bound iron in this study should permit a better understanding of iron in the oxidative status in the animals.

The concentrations of zinc varied but remained within the range established at T0 (2.18 to $35.92 \mu \mathrm{mol} / \mathrm{L}$ ), with a trend towards an increase. Statistical analysis showed differences in average levels by postpartum day 28 when compared to $\mathrm{T} 1, \mathrm{~T} 2$ and $\mathrm{T} 3$. The mean zinc concentration was $29.3 \%$ higher at 42 days postpartum compared to $\mathrm{T} 0$. Zinc requirements are probably higher during the reproductive phase of animals compared to other phases since this element participates in various processes such as reproduction, fetal growth, milk production, formation of antioxidant enzymes, DNA stabilization, hormone receptors, and immunological activities. Although there are many causes that could explain the increase in serum zinc levels, the animals in this experiment did not experience major complications such as infections, intoxication or feed deprivation. Thus, the trend of this mineral suggests that higher serum zinc levels, accompanied by an increase in antioxidant enzymes, act together to ensure a satisfactory antioxidant response, in agreement with Powell (2000) and Koury (2003).

Albumin concentrations were between 32.16 and $37.22 \mathrm{~g} / \mathrm{L}$ at some time points, i.e., within the reference range reported in the literature for this species (27 to 38g/L) (Gonzáles and Silva, 2006; Kaneko et al., 2008; Saut, 2008) and also within the baseline range (T0) of this experiment. Higher albumin concentrations were observed at 28 days postpartum. Similarly, Fagliari et al. (1998) obtained albumin concentrations of 32.8 and $33.9 \mathrm{~g} / \mathrm{L}$ at calving and 30 days postpartum, respectively. As observed in this study, Contreras (2000) reported lower albumin concentrations at the beginning of lactation, probably because the amino acid demand for milk protein synthesis. Hypoalbuminemia may also be present by others causes as the acute inflammatory response. Albumin was positively correlated with SOD and zinc (31\% and $22 \%$, respectively).

Since the concentration of albumin remained within the physiological limits established for the species throughout the experimental period, the causes of its variation are probably related to small physiological alterations or alterations in animal management, such as dietary changes, differences in temperature between time points, and variations in water availability, as postulated by other authors (Contreras, 2000; Thrall, 2006). However, it cannot be ruled out that the increase in albumin is due to its participation in the antioxidant defense.

Serum total bilirubin tended to decrease during the transition period. There was a significant difference between the values observed during the first 14 days postpartum and those obtained at 28 days postpartum, although they remained within the reference range established at T0 (2.22 to $6.96 \mu \mathrm{mol} / \mathrm{L})$. Opposite result was reported by Lemos (2015) who observed an increase in total bilirubin from the prepartum to the postpartum period. Hyperbilirubinemia is known to be associated with an increase of antioxidant defenses such as the increase in SOD and GSHPx and with a decrease of oxidants in several species. Although there was no significant correlation between total bilirubin and albumin, the result expected in this study would be an increase during the postpartum period. A correlation was observed between total bilirubin and copper which, although of medium 
magnitude, was positive $(0.30 ; \mathrm{p}<0.0001)$, supporting the decreasing trend of the analyte found.

The present results demonstrate that the minerals and metabolites analyzed work together with the increased in the activities of antioxidative enzymes to ensure a response to the oxidative imbalance generated. The periods of pregnancy, calving and milk production are characterized by dynamic changes in the body that increase oxygen consumption and alter the use of energy by different systems. In addition to the increased ROS production and the larger number of macrophages in the placenta during pregnancy, animals can develop nutritional imbalances, with these factors favoring oxidative stress. In this case, in addition to cellular respiration, the damage to tissues and organs is the result of immune reactions that contribute to the formation of ROS in the body (Lykkesfeldt and Svendsen, 2007). In dairy Gyr cattle, uterine involution occurs at about 29 days postpartum (González Sanchéz et al., 1999). In the present study, this period was characterized by the greatest alterations in enzyme activity, with an increase of about $300 \%$ in SOD and of $36 \%$ in GSH-Px at the end of the experimental period, accompanied by biochemical adaptations to ensure an effective antioxidant response.

In addition to these results, the use of a homogenous sample group permitted to establish, for the first time, a reference range for different biochemical analytes that are involved in the antioxidant profile, as well as for the activities of SOD and GSH-Px. These data can be used in future studies for interpretation on Gyr cattle.

Considering the conditions of this experiment, can be concluded that the peripartum period causes oxidative stress in Gyr dairy heifers, which respond with an increase in enzymatic antioxidant activity and important changes in the homeostasis.

\section{ACKNOWLEDGEMENTS}

This work was supported by Fapesp (2015/24174-3). The authors thank CNPq (Process n. 302636-2017/0) and CAPES for the granting scholarships to the authors and Epamig for the animals and structural local.

\section{REFERENCES}

ABBA, M.; LUCA, J.; MATTIOLI, G. et al. Clastogenic effect of copper deficiency in cattle. Mutat. Res. Genet. Toxicol. Environ. Mutagen., v.466, p.51-55, 2000.

AZAB, H.A.; BANCI, L.; BORSARI, M. et al. Redox chemistry of superoxide dismutase. Cyclic voltammetry of wild-type enzymes and mutants on functionally relevant residues. Inorg. Chem., v.31, p.4649-4655, 1992.

BERNABUCCI, U. et al. Markers of Oxidative Status in Plasma and Erythrocytes of Transition Dairy Cows During Hot Season. Journal of Dairy Science, [s.1.], v. 85, n. 9, p.2173-2179, set. 2002.

BERNABUCCI, U.; RONCHI, B.; LACETERA, $\mathrm{N}$. et al. Influence of body condition score on relationships between metabolic status and oxidative stress in periparturient dairy cows. $J$. Dairy Sci., v.88, p.2017-2026, 2005.

CASTILLO, C.; HERNANDEZ, J.; BRAVO, A. et al. Oxidative status during late pregnancy and early lactation in dairy cows. Vet. J., v.169, p.286-292, 2005.

CONTRERAS, P. Indicadores do metabolismo proteico utilizados nos perfis metabólicos de rebanhos. In: GONZÁLEZ, F.H.D.; BARCELLOS, J.O.; OSPINA, H.; RIBEIRO, L.A.O. (Eds.). Perfil metabólico em ruminantes: seu uso em nutrição e doenças nutricionais. Porto Alegre: Universidade Federal do Rio Grande do Sul, 2000. 108p.

DRACKLEY, J.K. Biology of dairy cows during the transition period: the final frontier? J. Dairy Sci., v.82, p.2259-2273, 1999.

EINSELE, H.; CLEMENS, M.R.; WEGNER, U. et al. Effect of free radical scavengers and metal ion chelators on hydrogen peroxide and phenylhydrazine induced red blood cell lipid peroxidation. Free Radic. Res. Commun., v.3, p.257-263, 1987.

FAGLIARI, J.J.; SANTAN, A.E.; MARCHIO, W. et al. Constituintes sanguíneos de vacas das raças Nelore (Bos indicus) e Holandesa (Bostaurus) e de bubalinos (Bubalus bubalis) da raça Murah durante a gestação, no dia do parto e no puerpério. Arq. Bras. Med. Vet. Zootec., v.50, p.273-282, 1998. 
GLANTZOUNIS， G.; TSIMOYIANNIS， E.; KAPPAS, A. et al. Uric acid and oxidative stress. Curr. Pharm. Design., v.11, p.4145-4151, 2005.

GONZÁLEZ SANCHÉZ， J.P.; BIANCHINI SOBRINHO, E.; GONÇALVES, A.A.M. Involução uterina em um rebanho Gir leiteiro segundo o período pós-parto e o número de parições. Arq. Bras. Med. Vet. Zootec., v.51, p.345-351, 1999.

GONZÁLEZ, F.H.D.; SCHEFFER, J.F.S. Perfil sanguíneo: ferramenta de análise clínica, metabólica e nutricional. In: SIMPÓSIO DE PATOLOGIA CLÍNICA VETERINÁRIA DA REGIÃO SUL DO BRASIL, 2003, Porto Alegre. Anais... Porto Alegre: UFRGS, 2003. p.73-89.

GONZÁLEZ, F.H.D.; SILVA, S.C. Introdução à bioquímica clínica veterinária. 2.ed. Porto Alegre: UFRGS, 2006. 358p.

HALLIWELL, B. Antioxidant characterization: methodology and mechanism. Biochem. Pharmacol., v.49, p.1341-1348, 1995.

HÖTZEL, M.J.; MACHADO FILHO, L.C.P.; YUNES, M.C. et al. Influência de um Ordenhador aversivo sobre a produção leiteira de vacas da raça Holandesa. Rev. Bras. Zootec., v.34, p.1278-1284, 2005.

KANEKO, J.J.; HARVEY, J.W.; BRUSS, M.L. (Ed.). Clinical biochemistry of domestic animals. 6.ed. New York: Academic Press, 2008. 936p.
KOURY, J.C.; DONANGELO, C.M. Zinco, estresse oxidativo e atividade física. Rev. Nutr., v.16, p.433-441, 2003.

LEBLANC, S. Monitoring metabolic health of dairy cattle in the transition period. J. Reprod. Dev., v.56, p.29-35, 2010.

LEMOS, J.C. Perfil bioquímico e status oxidativo em vacas leiteiras mestiças no período de transição em clima tropical. 2015. 66f. Dissertação (Mestrado em Medicina Veterinária) - Faculdade de Medicina Veterinária, Universidade Estadual do Ceará, Fortaleza, CE.

LYKKESFELDT, J.; SVENDSEN, O. Oxidants and antioxidants in disease: Oxidative stress in farm animals. Vet. J., v.173, p.502-511, 2007.

POWELL, S.R. The antioxidant properties of zinc. J. Nutr., v.130, p.1447-1454, 2000.

SAS/STAT user's guide: Version 9.2. Cary, NC: SAS Institute, Inc., 2012.

SAUT, J. P. E. Influência do puerpério e da retenção dos anexos fetais no proteinograma de fêmeas bovinas da raça Holandesa, criadas no Estado de São Paulo. 2008. 116f. Tese (Doutorado em Medicina Veterinária) - Universidade de São Paulo. Faculdade de Medicina Veterinária e Zootecnia, São Paulo, 2008.

THRALL, M.A. Hematologia e bioquímica clínica veterinária. In: THRALL, M.A. Hematologia e bioquímica clínica veterinária. Fort Collins: Roca, 2006. 582p. 